\title{
LA-ICP-MS ANALYSIS OF LATE BRONZE AGE BLUE GLASS BEADS FROM GUROB, EGYPT.
}

Kemp. V. ${ }^{1 *}$, McDonald, A. ${ }^{2}$, Brock, F. ${ }^{1}$ and Shortland A. J. ${ }^{1}$.

1. Cranfield Forensic Institute, Cranfield University, Defence Academy of the United Kingdom, Shrivenham, Oxfordshire, SN6 8LA

2. University of Glasgow, 11 Eldon Street, Glasgow, G3 6NH

Corresponding author* Cranfield Forensic Institute, Cranfield University, Defence Academy of the United Kingdom, Shrivenham, Oxfordshire, SN6 8LA. E-mail address: v.kemp@cranfield.ac.uk (V. Kemp)

Keywords: Glass, Late Bronze Age, Egypt, Mesopotamia, Gurob, Harem, Beads, LA-ICP-MS.

\section{HIGHLIGHTS}

- The blue glass beads represent some of the earliest glass, from the reigns of Amenhotep I -Tuthmosis III (1525 - 1425 BC) and rare Mesopotamian glass to be found in Egypt.

- They represent the first confirmation of iconographic and textual references to the glass being imported into Egypt from Mesopotamia in this period.

- These glass beads represent luxury items being brought into the country probably by high-ranking foreign women, possibly in connection with the harem.

- Analysis of the major and minor elements indicates that the beads were made from two main distinct batches of glass.

\section{ABSTRACT}

LA-ICP-MS analysis was undertaken on 37 blue glass beads excavated from a tomb in Gurob, in the Southern Fayum region of Egypt. The tomb was undisturbed, contained the remains of seven females and two children, and dated between the reigns of Amenhotep I (1525-1504 BC) and Tuthmosis III (1479-1425 BC). The glass beads are coloured by copper and the trace element concentrations are compositionally consistent with glasses from Mesopotamia, rather than from Egypt. Therefore, these glass beads represent a rare example of Mesopotamian glass to be discovered in Egypt, in addition to being some of the earliest glass found. Gurob is known to have been the site of a 'harem palace' established in the reign of Tuthmosis III (1479-1425 BC), the 
implication being that these beads represent luxury items transported into Egypt by high-ranking foreign women, possibly in connection with the harem palace.

\section{INTRODUCTION}

The first regular finds of glass appear in the archaeological records of Mesopotamia and Egypt around $1500 \mathrm{BC}$ (Lilyquist et al. 1993, p23; Nicholson, 1993, p45-46; Tite \& Shortland. 2008, p209), but the exact geographical source of the first glassmaking is still a matter of debate. Excavations have provided supporting physical evidence of glass making sites at Qantir and Amarna in Egypt (Lucas and Harris, 1962 p179-194;; Jackson and Nicholson, 2007 p13-25; Pusch and Rehren, 2007; Smirniou and Rehren, 2011; ), and glassworking at Tell Brak and Nuzi in modern-day Syria and northern Iraq respectively (Henderson, 1998; Shortland et al., 2017). However, the evidence for the manufacture of glass from raw materials is often inferred, particularly in Mesopotamia where poor preservation conditions impact the successful recovery of glass artefacts and no glassmaking site has been confidently identified (Shortland et al. 2007; Shortland, 2012, p49). It is very rare to find glass identified as Egyptian in Mesopotamia or vice versa (Walton et al. 2009); the sole example being two green glass rods excavated from Amarna in Egypt, trace element analysis of which suggested that the composition was similar to glasses of Mesopotamian origin (Varberg et al. 2016).

Glass was an extremely valuable commodity in the Late Bronze Age, the ownership of which was closely controlled by, and limited to, royalty or the elite. Therefore, it played a significant role in the elaborate ritual of gift exchange between Egypt, the Near East and their vassal states (Liverani, 2000, p 24). Contemporary textual evidence for the supply of glass to Egypt appears in the Amarna letters (EA 148, EA 235, EA 314, EA 323 and EA 331), cuneiform tablets that detail the diplomatic correspondence between Egyptian officials and vassal states during the reigns of Amenhotep III (1391-1353 BC) and Akhenaten (1353-1333 BC) (Moran, 1992; Shortland, 2012 p147; Rehren, 2016). The text explicitly documents the 'ordering' of glass from the SyriaPalestinian states by the King of Egypt. In addition, the Hall of the Annals in Karnak, dated to the mid $15^{\text {th }}$ Century (Spalinger, 1977) illustrates the apparent import of glass into Egypt from the Levant and Syria, either as spoils of the military campaigns undertaken by Tuthmosis III, or 'gifts' made in tribute by subordinate foreign rulers (Wreszinski, 1923-1940, p50). Physical evidence for the import of glass in this early period has not been found until the results reported in this paper. 
Laser Ablation Inductively Coupled Plasma Mass Spectrometry (LA-ICP-MS) can be used to quantify geologically significant trace elements in glass, enabling the region of production to potentially be inferred (Shortland et al. 2007; Walton et al. 2009). Trace elements are introduced during the glassmaking procedure by the addition of raw materials rather than during the glassworking process, which may have occured at a different site or another country (Shortland, 2005; Jackson \& Nicholson, 2010). These compositional differences have been crucial in distinguishing between glasses manufactured in Egypt and the Near East.

The analysis and provenance of early examples of glass could provide fundamental supporting evidence for the location of primary sites capable of manufacturing glass from raw materials. The subsequent transport of glass and the patterns of exchange would contribute to the understanding of an important emerging technology and the subsequent exchange of its products. A number of mechanisms might be responsible for glass transportation between the two countries: direct diplomatic gifts, personal items brought by royalty, diplomatic parties, others of high status, or even movement of glassworkers. Diplomatic marriages were common in both Egypt and Mesopotamia (Bryan, 2000 p80), and it was customary that the intended bride would be joined by a substantial entourage (Snape, 2014, p48); it can be assumed that glass objects in the form of jewellery were among the personal effects of such elite retinues of women and potentially part of other gifts. Royal harems in Egypt would almost certainly have included foreign women who were married to the king to secure diplomatic relationships especially with the Hittite and Mitanni nations (Shaw, 2011). Examples of this include the three 'Foreign Wives' of Tuthmosis III, who may have been residents of the palace at Gurob discussed here, but were buried near Thebes (Lilyquist, 2004, p336). Although little is known of the princesses, they were described as 'Asiatic' women of high status and their tomb contained elaborate headdresses and jewellery inlayed with some of the first glass known, and possibly of foreign, perhaps Mitanni, styles (Feucht 1999, p385). Another later example is the diplomatic marriage between Amenhotep III and Mitanni princess Gilukhepa where it is recorded on a commemorative scarab that she was accompanied by 317 'chief women of the harem' (Snape, 2014, p48). This indicates the size of a palace and the resources required to accommodate multiple royal marriages and associated retinues.

THE MEDINET EL-GHUROB SITE 
Medinet el-Ghurob, or Gurob, is located in the Faiyum region of Northern Egypt and is of particular interest as it is the site of the only palace identified as a harem (Shaw, 2011). It has been proposed that the harem palace was established during the reign of Tuthmosis III (1479-1425 BC) with the primary purpose of accommodating royal foreign women who had been married to the King (Hodgkinson, 2017 p188). The palace was situated near the ancient town of Mer-wer and thrived during the reign of Amenhotep III (1390-1352 BC), expanding to provide for larger structures including a fort and a temple, as well as cemeteries and areas of local settlement. The palace itself is a large construction, the enclosure measuring approximately $240 \times 225 \mathrm{~m}$, which served as a ceremonial centre as well as having an administrative function (Hodgkinson, 2017 p192). As semi-independent institutions, harems had autonomous economic importance, and therefore significance. The harem palace at Gurob would have also accommodated senior royal wives, lesser wives and concubines in addition to their staff, servants and the harem officials (Kemp, 2006, p288).

In 1920, Brunton and Engelbach excavated the main New Kingdom cemetery at Gurob and discovered three undisturbed tombs at its northernmost point. The three tombs were distinctly separate, located approximately 365 meters from the main concentration of burials and subsequently labelled as Tombs 20, 26 and 27 . Tomb 27 was the largest of the three and contained the remains of seven females, two children and their associated grave goods (Brunton and Engelbach, 1927). These goods comprised twenty-six pottery vessels, one brick-red handled pot, and a variety of cosmetic items including several kohl pot and a mirror, likely bronze. The smaller finds, including the beads, were scattered by the collapse of the roof and the exact location in the tomb could not be recorded once the tomb was entered. The smaller finds were listed as twenty-nine scarab-like beads, some of which were mounted in silver or gold, and strings of stone and glass beads. The excavators asserted that the three tombs probably belonged to a family group and determined the date by examination of the grave goods as being from the reign of Amenhotep I, but caveated the date by stating that the ceramic vessels were customarily dated slightly later to the reign of Tuthmosis III (Brunton \& Engelbach, 1927, p10). It is inferred that the women might have a foreign origin as there is a notable lack of shabtis and canopics in all three of the tombs in the family group, important parts of the Egyptian burial ritual (Ikram, 2015 p129) and other foreign objects are present, for example a spindle bottle. The isolated position of the tomb, the all female nature of the dead and the "foreigness" speculated on by the excavators all suggest the possibility is that these women were part of the harem and/or its staff. 
This study reports the analysis of one of the finds from Tomb 27: a string of blue and clear beads, now in the Hunterian Museum, Glasgow (D.1921.48, Figure 1).

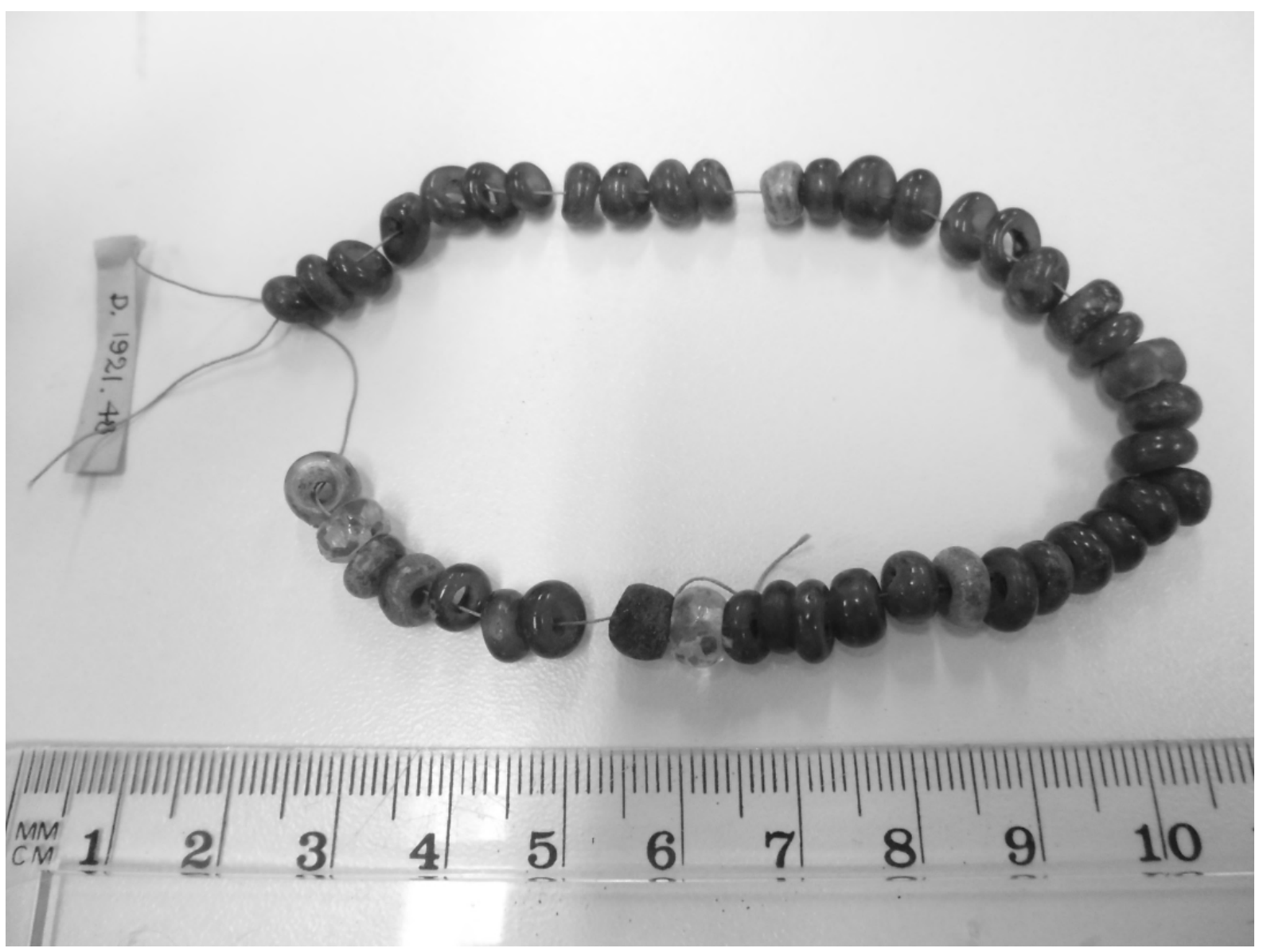

Figure 1. Beads excavated from Tomb 27, Gurob, Egypt in 1920. Bead B1 is lower left and the beads were numbered sequentially anticlockwise to B44 (Hunterian Museum Glasgow, D.1921.48)

\section{METHODOLOGY}

D.1921.48 is a string of forty-four beads; beads $1,2,9,15,24$ and 33 are transparent quartz with a partial blue glaze on the surface. This paper reports the analysis of 37 of the remaining 38 beads all of which are made of translucent, blue glass. The single missing bead was bead 28, which fell out of focus during the run; therefore the results have been omitted from the final reporting. Only 37 beads are therefore discussed in the results. 
Table 1. Average results of the Corning A secondary standards $(n=6)$, compared to two sets of reference values - Shortland and Vincenzi use the values, Wagner a slightly different set (Vicenzi et al., 2002; Shortland et al., 2007; Wagner et al., 2012). Values in ppm.

\begin{tabular}{|c|c|c|c|c|c|c|c|}
\hline & \multicolumn{3}{|c|}{$\mathrm{n}=6$ Corning $\mathrm{A}$, } & \multicolumn{2}{|c|}{$\begin{array}{l}\text { Shortland et al.;2007/ } \\
\text { Vicenzi et al. } 2002\end{array}$} & \multicolumn{2}{|c|}{ Wagner et al. 2012} \\
\hline & Average & St dev & prec & $\begin{array}{c}\text { ref } \\
\text { values }\end{array}$ & deltawt\% & $\begin{array}{c}\text { ref } \\
\text { values }\end{array}$ & deltawt $\%$ \\
\hline $\mathrm{Li}$ & 47 & 0.8 & 1.7 & 46 & 2.4 & 51 & -7.8 \\
\hline B & 548 & 64.4 & 11.8 & 537 & 2 & 851 & -35.6 \\
\hline $\mathrm{Na}$ & 101387 & 1050 & 1 & 106083 & -4.4 & 99407 & 2 \\
\hline Mg & 16439 & 242 & 1.5 & 16043 & 2.5 & 15078 & 9 \\
\hline Al & 5040 & 134 & 2.7 & 5291 & -4.8 & 4339 & 16.2 \\
\hline $\mathrm{Si}$ & 316488 & 1746 & 0.6 & 310883 & 1.8 & 316768 & -0.1 \\
\hline K & 21031 & 2022 & 9.6 & 22639 & -7.1 & 28714 & -26.8 \\
\hline $\mathrm{Ca}$ & 36872 & 615 & 1.7 & 35954 & 2.6 & 35311 & 4.4 \\
\hline $\mathrm{Ti}$ & 4468 & 286 & 6.4 & 4226 & 5.7 & 4428 & 0.9 \\
\hline $\mathrm{Cr}$ & 19 & 0.7 & 3.7 & 17.9 & 6.2 & 21 & -7.4 \\
\hline $\mathrm{Mn}$ & 7221 & 437 & 6.1 & 6921 & 4.3 & 8752 & -17.5 \\
\hline $\mathrm{Fe}$ & 6654 & 323 & 4.9 & 6537 & 1.8 & 6841 & -2.7 \\
\hline Co & 1182 & 128 & 10.9 & 1188 & -0.5 & 1336 & -11.6 \\
\hline $\mathrm{Ni}$ & 170 & 6.5 & 3.8 & 160 & 6.3 & 181 & -5.9 \\
\hline $\mathrm{Cu}$ & 9346 & 346 & 3.7 & 7842 & 19.2 & 8786 & 6.4 \\
\hline $\mathrm{Zn}$ & 502 & 82 & 16.3 & 410 & 22.5 & 386 & 30.3 \\
\hline $\mathrm{Rb}$ & 86.8 & 2.7 & 3.1 & 81.5 & 6.5 & 82 & 5.5 \\
\hline $\mathrm{Sr}$ & 951 & 13.9 & 1.5 & 860 & 10.5 & 897 & 6 \\
\hline$Y$ & 0.28 & 0.0 & 6.8 & n.d. & n.d. & n.d. & n.d. \\
\hline $\mathrm{Zr}$ & 44 & 1.7 & 4 & 39.9 & 10.9 & 37 & 19.5 \\
\hline Sn & 1490 & 92.4 & 6.2 & 1194 & 24.8 & 1357 & 9.8 \\
\hline $\mathrm{Sb}$ & 14334 & 1521 & 10.6 & 10649 & 34.6 & 14002 & 2.4 \\
\hline $\mathrm{Ba}$ & 4605 & 175 & 3.8 & 3905 & 17.9 & 4122 & 11.7 \\
\hline La & 0.34 & 0.0 & 12.4 & 0.28 & 20.7 & n.d. & n.d. \\
\hline $\mathrm{Ce}$ & 0.27 & 0.0 & 9.1 & 0.24 & 12.4 & n.d. & n.d. \\
\hline $\mathrm{Pb}$ & 694 & 68.1 & 9.8 & 595 & 16.7 & 678 & 2.5 \\
\hline $\mathrm{Bi}$ & 8.6 & 0.6 & 7.2 & 7.8 & 9.8 & 9 & -4.5 \\
\hline Th & 0.3 & 0.0 & 6.5 & 0.3 & 2.5 & n.d. & n.d. \\
\hline U & 0.18 & 0.0 & 9 & 0.16 & 13.5 & n.d. & n.d. \\
\hline
\end{tabular}

The beads were ablated directly in the large sample chamber of an ESI New Wave laser ablation system attached to a Thermo X-Series II ICP-MS. The laser ablation settings and ICPMS system were optimised using a series of standards to determine the working conditions used. The laser spot diameter was 80 microns with an energy of $0.42 \mathrm{~mJ}$, pulsing at $10 \mathrm{~Hz}$. The helium carrier gas flow rate was $500 \mathrm{ml} \mathrm{min}^{-1}$ through the laser into an 
argon stream for the ICPMS. The nebuliser flow rate was $0.6-0.7 \mathrm{~L} \mathrm{~min}^{-1}$. The spectrometer dwell time was $20 \mathrm{~ms}$ per mass, and 10 sweeps were averaged. The beads were analysed in three analytical runs, each interposed with gas blank analyses and calibrated against NIST SRM 610 and 612 reference glasses employing the consensus values (Jochum et al. 2011). Two measurements of the Corning A standard were carried out in each analytical run, one at the beginning and one at the end and evaluated against the accepted values. Vincenzi and Shortland ues the same sets of values, Wagner slightly different ones (Vicenzi et al. 2002; Shortland et al. 2007; Wagner et al. 2012), see Error! Reference source not found.. The results on the Corning A standard show that the majority of the elements were in good agreement with accepted values; when expressed as a percentage difference between the ascertained and accepted values (RD) the values are typically better than $20 \%$. It should also be noted that the Corning A standard was never intended as an LA-ICP-MS standard, so some trace elements were never intended to be used as standard values. However, agreement in general is good.

Each bead was subjected to three measurements on one spot and the results were averaged. The beads were not cleaned before analysis; however, preablation would remove the very outermost weathering and care was taken to avoid apparent patches of corrosion. Most of the beads are in good condition although some exhibit some surface corrosion mainly in the form of pitting and mottling. During an initial examination of the beads small bubbles in the glass were observed below the surface and were avoided.

The results were calibrated using the mathematical approach first proposed by Gratuze (1999) as an alternative to the use of an internal standard. The protocol used here was derived from that and follows van Elteren et al. (2009). This essentially works in a similar fashion to a normalised EDS system on an SEM. It assumes that all elements are measured and calculates oxygen by stoichiometry. The total is then normalised to $100 \mathrm{wt} \%$ and either presented as weight percent oxide or converted back to elemental ppm.

\section{RESULTS}

The data is presented in Table 2

Major Elements 
Table 1: Results of LA-ICP-MS analyses of the blue beads (Oxides in percent oxide; trace elements in ppm).

\begin{tabular}{|c|c|c|c|c|c|c|c|c|c|c|c|c|c|c|c|c|c|c|c|c|c|c|c|c|c|c|c|c|c|}
\hline ead & $\mathrm{Na}^{2} \mathrm{O}$ & $\mathrm{MgO}$ & $\mathrm{Al}^{2} \mathrm{O}^{3}$ & $\mathrm{SiO}^{2}$ & $\mathrm{~K}^{2} \mathrm{O}$ & $\mathrm{CaO}$ & $\mathrm{Fe}^{2} \mathrm{O}^{3}$ & CuO & Li & B & $\mathrm{Ti}$ & $\mathrm{Cr}$ & $\mathrm{Mn}$ & Co & $\mathrm{Ni}$ & $\mathrm{Cu}$ & $\mathrm{Zn}$ & $\mathrm{Rb}$ & $\mathrm{Sr}$ & Y & $\mathrm{Zr}$ & Sn & Sb & $\mathrm{Ba}$ & La & $\mathrm{Ce}$ & & $\mathrm{Bi}$ & Th \\
\hline B3 & 16.6 & 5.2 & 1.0 & 68.0 & 2.3 & 5.2 & 0.6 & 1.0 & 17 & 136 & 269 & 33 & 254 & 18 & 12 & 7658 & 20 & 10 & 342 & 2.6 & 11.0 & 3.6 & 1.7 & 62 & 2.2 & 7.5 & & 0.2 & 0.6 \\
\hline B4 & 17.2 & 5.6 & 1.0 & 65.6 & 3.0 & 5.6 & 0.7 & 0.9 & 21 & 122 & 385 & 37 & 303 & 16 & 16 & 7422 & 38 & 17 & 421 & 2.7 & 15.5 & 11.8 & 10.9 & 49 & 2.5 & 5.3 & & 0.2 & 0.7 \\
\hline B5 & 13.2 & 6.7 & 0.5 & 69.5 & 3.3 & 5.0 & 0.3 & 1.2 & 31 & 111 & 161 & 27 & 224 & 14 & 12 & 9212 & 18 & 21 & 356 & 1.6 & 6.9 & 1.1 & 3.4 & 29 & 1.3 & 3. & & 0.1 & 0.3 \\
\hline B6 & 16.9 & 5.6 & 1.0 & 66.3 & 3.0 & 5.5 & 0.6 & 0.9 & 21 & 151 & 331 & 40 & 274 & 13 & 15 & 6965 & 24 & 17 & 420 & 2.5 & 14.8 & 6.1 & 6.4 & 50 & 2.2 & 5. & & 0.1 & 0.6 \\
\hline B7 & 18.0 & 6.7 & 0.5 & 64.0 & 3.6 & 5.4 & 0.3 & 1.2 & 38 & 84 & 170 & 30 & 247 & 18 & 12 & 9569 & 20 & 15 & 373 & 1.9 & 9.0 & 1.1 & 3.6 & 27 & 1.6 & 3. & & 0.1 & 0.4 \\
\hline B8 & 18.2 & 6.2 & 0.7 & 65.2 & 3.1 & 4.9 & 0.4 & 1.0 & 24 & 167 & 233 & 20 & 246 & 19 & 13 & 7798 & 19 & 17 & 392 & 2.1 & 9.6 & 1.6 & 0.7 & 37 & 1.8 & 4. & & 0.1 & 0.4 \\
\hline B10 & 18.3 & 6.6 & 0.6 & 64.3 & 3.3 & 5.3 & 0.3 & 1.1 & 37 & 111 & 169 & 22 & 218 & 14 & 12 & 8535 & 38 & 15 & 360 & 1.8 & 8.4 & 7.1 & 5.5 & 112 & 1.4 & 3. & & 0.2 & 0.4 \\
\hline B11 & 18.8 & 6.7 & 0.8 & 62.9 & 3.4 & 5.5 & 0.4 & 1.0 & 29 & 193 & 255 & 27 & 237 & 16 & 13 & 7878 & 47 & 14 & 459 & 2.4 & 12.8 & 4.4 & 6.1 & 37 & 1.7 & 3. & & 0.2 & 0.5 \\
\hline B12 & 18.5 & 6.4 & 0.5 & 63.9 & 3.5 & 5.2 & 0.4 & 1.2 & 39 & 88 & 192 & 21 & 254 & 17 & 13 & 9428 & 35 & 17 & 361 & 1.8 & 8.6 & 3.5 & 20.2 & 28 & 1.6 & 3. & & 0.1 & 0.4 \\
\hline B13 & 16.9 & 5.7 & 1.1 & 66.3 & 2.7 & 5.7 & 0.6 & 0.8 & 21 & 159 & 323 & 39 & 270 & 13 & 14 & 6648 & 21 & 16 & 434 & 2.8 & 16.8 & 50.3 & 6.4 & 50 & 2.3 & 5. & & 0.1 & 0.6 \\
\hline B14 & 16.3 & 5.3 & 1.1 & 68.0 & 2.0 & 5.4 & 0.6 & 0.9 & 17 & 139 & 275 & 28 & 248 & 17 & 11 & 7393 & 18 & 8 & 361 & 3.2 & 13.4 & 9.4 & 0.5 & 62 & 2.4 & 5. & & 0.2 & 0.7 \\
\hline B16 & 18.8 & 6.9 & 0.6 & 63.9 & 2.8 & 5.3 & 0.3 & 1.0 & 40 & 106 & 186 & 25 & 213 & 13 & 12 & 8212 & 28 & 15 & 353 & 1.8 & 7.9 & 6.0 & 4.1 & 24 & 1.3 & 3. & & 0.2 & 0.3 \\
\hline B17 & 15.5 & 5.4 & 1.3 & 68.1 & 2.1 & 5.6 & 0.6 & 0.9 & 16 & 139 & 309 & 27 & 248 & 17 & 16 & 7064 & 41 & 8 & 363 & 3.2 & 13.4 & 4.0 & 4.6 & 66 & 2.5 & 6. & & 0.2 & 0.7 \\
\hline B18 & 16.8 & 5.5 & 1.1 & 67.5 & 1.9 & 5.4 & 0.6 & 0.9 & 19 & 137 & 315 & 22 & 242 & 18 & 11 & 6979 & 19 & 10 & 365 & 3.2 & 12.8 & 2.8 & 1.2 & 65 & 2.3 & 5. & & 0.3 & 0.7 \\
\hline B19 & 16.7 & 5.7 & 1.1 & 66.4 & 2.7 & 5.7 & 0.6 & 0.8 & 21 & 143 & 321 & 41 & 274 & 13 & 15 & 6677 & 32 & 17 & 448 & 2.9 & 16.9 & 29.6 & 10.5 & 54 & 2.4 & ל. & & 0.2 & 0.6 \\
\hline B20 & 17.7 & 5.8 & 1.1 & 65.8 & 2.3 & 5.5 & 0.6 & 0.9 & 23 & 151 & 344 & 45 & 276 & 13 & 15 & 6897 & 30 & 16 & 416 & 2.8 & 16.5 & 47.3 & 6.8 & 45 & 2.2 & 5. & & 0.2 & 0.6 \\
\hline B21 & 18.1 & 4.8 & 0.8 & 64.2 & 3.8 & 6.4 & 0.4 & 1.1 & 16 & 111 & 239 & 24 & 227 & 9 & 15 & 8428 & 35 & 11 & 417 & 2.1 & 10.6 & 50.6 & 4.3 & 37 & 1.8 & 4. & & 0.1 & 0.5 \\
\hline B22 & 17.8 & 6.2 & 0.5 & 64.7 & 3.5 & 4.9 & 0.4 & 1.6 & 38 & 84 & 221 & 24 & 248 & 18 & 13 & 12788 & 97 & 15 & 337 & 1.6 & 9.7 & 25.2 & 6.8 & 27 & 1.5 & 3. & & 0.5 & 0.4 \\
\hline B23 & 15.8 & 5.2 & 1.0 & 68.2 & 2.5 & 5.3 & 0.7 & 1.0 & 17 & 106 & 283 & 25 & 280 & 21 & 12 & 7739 & 31 & 12 & 353 & 3.0 & 12.9 & 2.3 & 1.0 & 82 & 2.9 & 5. & & 0.2 & 0.8 \\
\hline B25 & 18.1 & 6.4 & 0.5 & 64.5 & 3.6 & 5.0 & 0.3 & 1.2 & 39 & 79 & 164 & 27 & 246 & 17 & 13 & 9515 & 41 & 16 & 356 & 1.8 & 8.2 & 84.8 & 4.5 & 31 & 1.7 & 3. & & 0.2 & 0.4 \\
\hline B26 & 17.0 & 5.3 & 1.0 & 66.6 & 2.9 & 5.3 & 0.6 & 0.9 & 21 & 120 & 320 & 40 & 305 & 17 & 16 & 7502 & 74 & 16 & 410 & 2.7 & 15.9 & 8.9 & 9.1 & 50 & 2.6 & 5. & & 0.3 & 0.7 \\
\hline B27 & 16.3 & 5.1 & 1.0 & 67.9 & 2.5 & 5.2 & 0.7 & 1.0 & 17 & 104 & 286 & 30 & 286 & 22 & 13 & 7958 & 28 & 9 & 349 & 2.9 & 13.2 & 19.1 & 3.0 & 69 & 2.8 & 5. & & 0.2 & 0.9 \\
\hline B29 & 16.4 & 5.4 & 1.0 & 66.8 & 3.0 & 5.5 & 0.6 & 0.9 & 22 & 111 & 353 & 51 & 297 & 16 & 15 & 7371 & 26 & 18 & 421 & 2.8 & 17.0 & 10.1 & 8.5 & 54 & 2.8 & 5. & & 0.2 & 0.7 \\
\hline B30 & 18.1 & 6.6 & 0.5 & 65.1 & 2.9 & 5.1 & 0.3 & 1.1 & 40 & 99 & 178 & 26 & 216 & 14 & 12 & 8567 & 25 & 15 & 347 & 1.8 & 9.7 & 15.3 & 3.4 & 24 & 1.4 & 4. & & 0.1 & 0.3 \\
\hline B31 & 16.7 & 5.6 & 1.1 & 66.3 & 2.8 & 5.7 & 0.6 & 0.9 & 21 & 111 & 337 & 39 & 306 & 16 & 15 & 7111 & 36 & 17 & 454 & 3.2 & 19.2 & 12.3 & 12.9 & 55 & 3.0 & 5. & & 0.2 & 0.8 \\
\hline B32 & 16.8 & 5.7 & 1.1 & 66.5 & 2.6 & 5.5 & 0.6 & 0.8 & 22 & 140 & 319 & 40 & 265 & 13 & 14 & 6619 & 113 & 15 & 435 & 3.0 & 17.4 & 22.2 & 9.2 & 52 & 2.4 & 5. & & 0.2 & 0.6 \\
\hline B33 & 16.2 & 5.3 & 1.1 & 66.9 & 3.0 & 5.5 & 0.7 & 0.9 & 21 & 112 & 369 & 39 & 303 & 16 & 16 & 7503 & 55 & 19 & 434 & 3.1 & 17.7 & 14.7 & 10.1 & 54 & 2.8 & 5. & & 0.2 & 0.7 \\
\hline B34 & 17.8 & 6.4 & 0.5 & 65.0 & 3.3 & 5.2 & 0.3 & 1.1 & 38 & 95 & 170 & 23 & 221 & 14 & 12 & 9075 & 87 & 18 & 368 & 1.8 & 8.5 & 9.1 & 7.8 & 29 & 1.5 & 3. & & 1.0 & 0.3 \\
\hline B35 & 15.9 & 3.7 & 1.4 & 69.5 & 2.9 & 4.2 & 0.8 & 1.1 & 17 & 64 & 451 & 19 & 174 & 4 & 19 & 8647 & 29 & 25 & 224 & 3.2 & 15.9 & 16.0 & 13.5 & 47 & 2.7 & 5. & & 1.0 & 0.8 \\
\hline B36 & 16.4 & 5.4 & 1.2 & 66.0 & 2.9 & 5.8 & 0.7 & 1.0 & 21 & 111 & 346 & 37 & 303 & 16 & 16 & 7622 & 79 & 17 & 451 & 3.2 & 19.2 & 12.8 & 11.8 & 59 & 3.1 & 6. & & 1.3 & 0.8 \\
\hline B37 & 15.9 & 5.2 & 1.0 & 68.5 & 2.2 & 5.3 & 0.7 & 0.8 & 17 & 121 & 318 & 24 & 246 & 17 & 11 & 7102 & 37 & 9 & 367 & 3.2 & 14.3 & 17.1 & 4.9 & 77 & 2.6 & 5. & & 0.3 & 0.7 \\
\hline B38 & 18.4 & 6.6 & 0.7 & 64.0 & 3.3 & 5.2 & 0.4 & 0.9 & 33 & 168 & 208 & 23 & 230 & 16 & 13 & 7537 & 50 & 14 & 433 & 2.3 & 11.9 & 11.1 & 5.5 & 34 & 1.7 & 3. & & 0.1 & 0.5 \\
\hline B39 & 18.0 & 6.7 & 0.6 & 64.9 & 2.8 & 5.3 & 0.3 & 1.1 & 41 & 99 & 197 & 33 & 218 & 14 & 11 & 8729 & 24 & 19 & 369 & 1.9 & 8.2 & 3.3 & 5.0 & 28 & 1.4 & 3. & & 0.1 & 0.3 \\
\hline B40 & 16.8 & 5.8 & 1.1 & 66.2 & 2.4 & 5.8 & 0.6 & 0.8 & 22 & 140 & 357 & 55 & 274 & 13 & 14 & 6607 & 32 & 18 & 456 & 3.1 & 18.8 & 4.8 & 9.2 & 48 & 2.4 & 5. & & 0.1 & 0.6 \\
\hline B41 & 16.2 & 5.4 & 1.1 & 68.5 & 1.8 & 5.2 & 0.6 & 0.9 & 18 & 130 & 304 & 25 & 246 & 17 & 12 & 7072 & 22 & 8 & 352 & 3.1 & 13.5 & 2.6 & 2.2 & 57 & 2.3 & 5. & & 0.1 & 0.7 \\
\hline B42 & 18.0 & 6.6 & 0.5 & 65.1 & 2.8 & 5.2 & 0.3 & 1.1 & 40 & 96 & 177 & 23 & 215 & 14 & 11 & 8454 & 19 & 15 & 363 & 1.8 & 9.7 & 3.9 & 3.4 & 26 & 1.4 & 3. & & 0.1 & 0.3 \\
\hline B43 & 16.7 & 5.7 & 1.0 & 66.5 & 2.8 & 5.5 & 0.6 & 0.9 & 21 & 137 & 317 & 40 & 269 & 13 & 15 & 6808 & 32 & 17 & 44 & 2.9 & 17.6 & 18.4 & 7.0 & 52 & 2.3 & 5. & & 0.1 & .0 \\
\hline
\end{tabular}

Page 1 of 15 
LA-ICP-MS analysis of the 37 blue glass beads showed that they are a soda lime silicate glass with typically 24\% $\mathrm{K}_{2} \mathrm{O}$ and 5-7\% MgO. This major element composition was consistent with a typical LBA, plant ash glass, which have high soda $\left(>15 \% \mathrm{Na}_{2} \mathrm{O}\right)$ and significant magnesia $(>3.0 \% \mathrm{MgO})$ and potash $\left(>2.0 \% \mathrm{~K}_{2} \mathrm{O}\right)$. All the beads were coloured by copper, with an average of $1.03 \mathrm{wt} \% \mathrm{CuO}$. Antimony was present only in trace levels $(<25 \mathrm{ppm} \mathrm{Sb})$, indicating that this was not deliberately added as an opacifier.

\section{DISCUSSION}

All 37 beads appear optically similar in colour however, interesting compositional differences could be observed in the major elements. Figure 2 shows $\mathrm{MgO}$ plotted against $\mathrm{CaO}$. Two groups are evident: a low $\mathrm{MgO}$ group with $\mathrm{MgO}$ content between $5.1 \mathrm{wt} \%$ to $5.8 \mathrm{wt} \%$, and a high $\mathrm{MgO}$ group with $\mathrm{MgO}$ content between $6.2 \mathrm{wt} \%$ to $6.9 \mathrm{wt} \%$. The beads in the high $\mathrm{MgO}$ group consistently contained the highest concentrations of $\mathrm{Na}, \mathrm{Li}$ and $\mathrm{Cu}$, and the lowest concentrations of Ti, Y, Mn, Zr. These distinct groupings indicate that the beads were potentially made from two main separate batches of glass, probably from slightly different plant ashes. Two outliers were observed, bead 21 and bead 35; potentially representing other batches. It is rare to be able to analyse all the beds of a necklace. More typically, one or two might be chosen. This is one of the advantages of LA-ICPMS, the very minimal damage caused in sampling allows more objects to be analysed and highlights interesting variations like this.

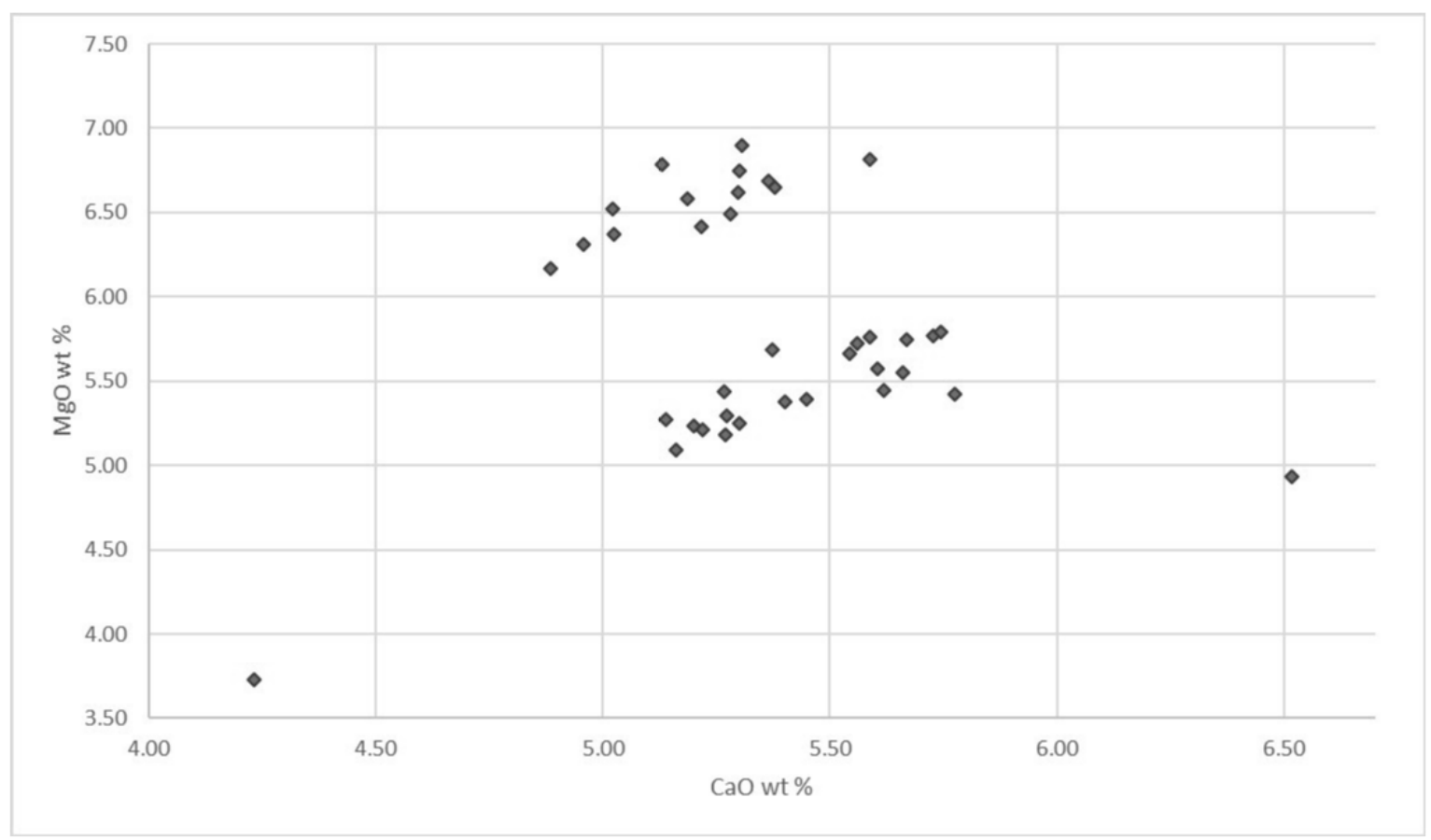


Figure 2. Covariation of $\mathrm{MgO}$ with $\mathrm{CaO}$ of the blue beads in wt $\%$ indicating two distinct main groups; high and low $\mathrm{MgO}$, with two outliers, potentially representing other batches.

Colourant

Egyptian copper-blue glasses tend to exhibit elevated levels of lead, arsenic and tin (Smirniou et al. 2013) which is attributed to the use of bronze as a source of copper for the colourant (Kaczmarczyk et al. 1983; Freestone, 1991; Shortland et al. 2000). In contrast, Near Eastern glasses tend to have these elements at no higher than trace levels. The beads analysed here contained only trace levels of tin and lead; averaging $17 \mathrm{ppm}$ and $19 \mathrm{ppm}$ respectively, indicating that a purer copper source was used, conforming with the characteristic colourant composition of Near Eastern glasses.

Trace Element Composition

LA-ICP-MS Trace element analysis can provide concentrations of $\mathrm{Cr}$, La, Ti and $\mathrm{Zr}$ which form a 'compositional fingerprint' which can be used to distinguish between LBA glasses of unknown sources (Shortland et al. 2007). Egyptian glasses exhibit a relatively low $\mathrm{Cr} / \mathrm{La}$ ratio with a higher, more variable $\mathrm{Zr} / \mathrm{Ti}$ ratio. Conversely, glasses originating from Mesopotamia exhibit lower, but consistent, $\mathrm{Zr} / \mathrm{Ti}$ ratios, and higher, more variable $\mathrm{Cr} / \mathrm{La}$ ratios, Mesopotamian glasses being relatively rich in $\mathrm{Cr}$.

The LA-ICP-MS trace element data (Table 2) shows that the glass beads contained relatively high concentrations of $\mathrm{Cr}$; between $18.7 \mathrm{ppm}$ to $54.2 \mathrm{ppm}$, with an average of $31 \mathrm{ppm}$, and lower concentrations of La (1.5 ppm to $3.1 \mathrm{ppm}$ averaging $2.4 \mathrm{ppm}$ ). This data was plotted against the trace element values obtained from the LA-ICP-MS analysis of glasses from known Egyptian and Mesopotamian origin (Shortland et al. 2007; Walton et al. 2009), and illustrated in Figure 3. The beads show a positive correlation with the Mesopotamian glasses, but it was observed that they have an overall higher average $\mathrm{Cr}$ concentration than the Mesopotamian glasses analysed in the Shortland (2007) and Walton (2009) studies. 


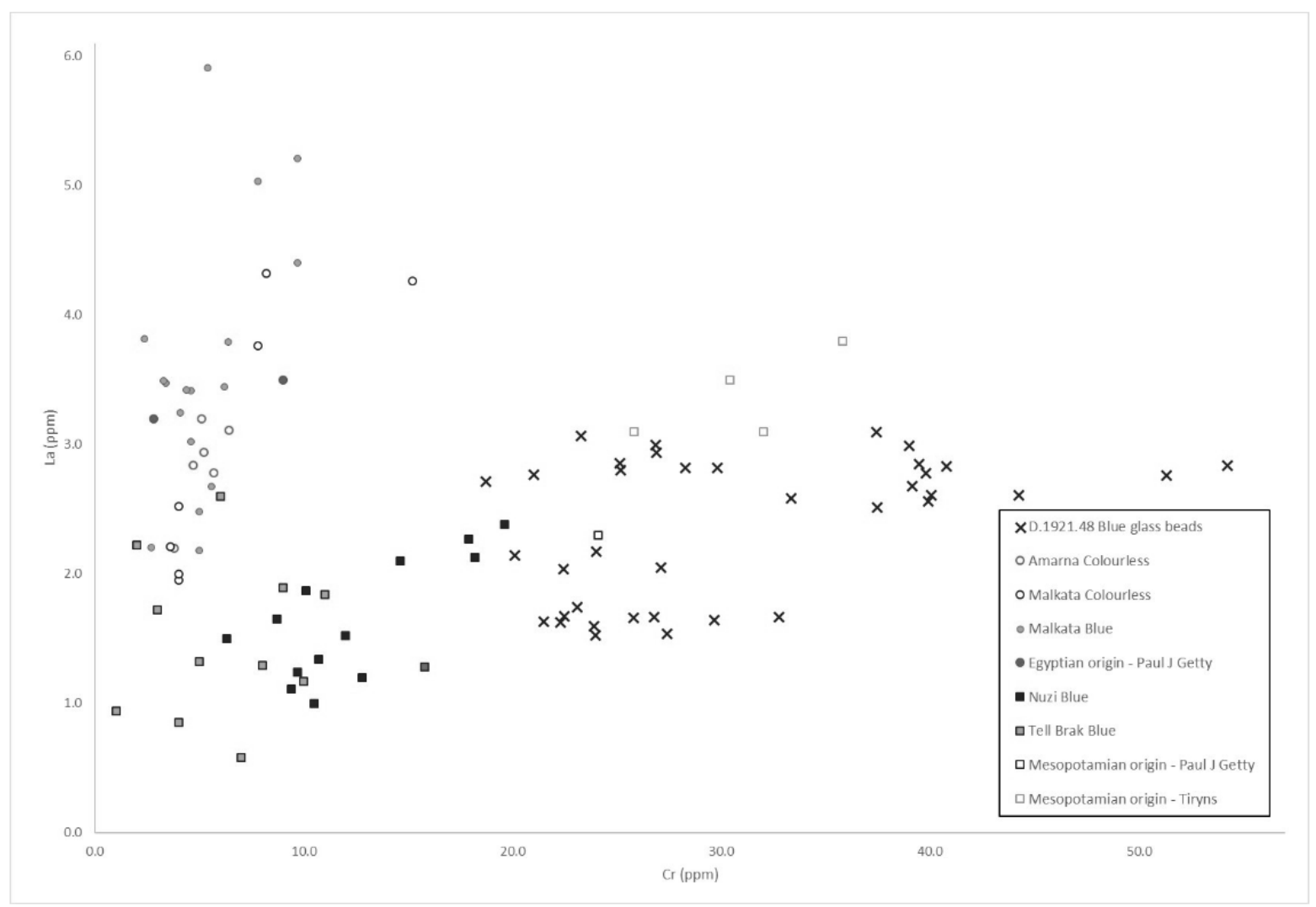

Figure 3. Covariation of $\mathrm{La}$ with $\mathrm{Cr}$ in the blue beads of unknown origin compared with Egyptian and Mesopotamian blue and colourless glasses of known origin (Shortland et al. 2007; Walton et al. 2009).

The Ti concentration of the beads ranged from $164 \mathrm{ppm}$ to $452 \mathrm{ppm}$ with an average of $274 \mathrm{ppm}$; the $\mathrm{Zr}$ concentration ranged from $7.0 \mathrm{ppm}$ to $19.2 \mathrm{ppm}$ with an average of $13 \mathrm{ppm}$. When plotted with the glasses of known origin, the trace element data from the beads are consistent with the composition of the Mesopotamian glasses, illustrated in Figure 4. Trace element compositions therefore strongly suggest that the beads are compositionally consistent with Near Eastern glasses and distinct from almost all the glass previously recovered and analysed from Egypt. They are also early, some of the earliest glass known in Egypt, which has implications for the study of where the first glass might have originated (see Shortland et al. 2017 for a summary).

Traditionally it has been assumed that glass originated in the Near East and this early Near Eastern glass in Egypt tends to support that. However, it is clear that there is glass nearly this early as this in Egypt, so it is far from clear which has priority (Shortland et al. 2017). 


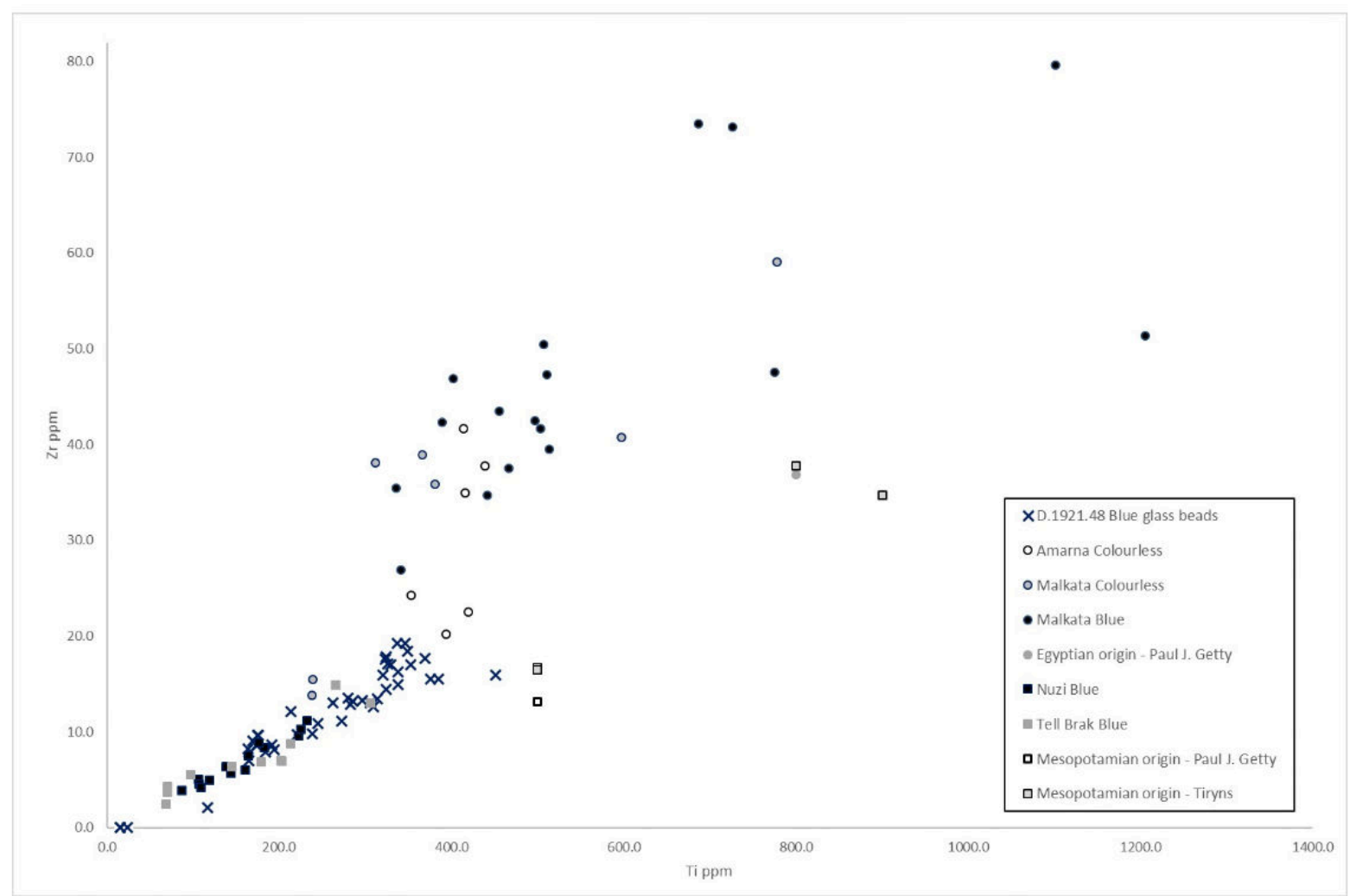

Figure 4. Covariation of $\mathrm{Zr}$ with $\mathrm{Ti}$ in the blue beads of unknown origin compared with Egyptian and Mesopotamian blue and colourless glasses of known origin (Shortland et al. 2007; Walton et al. 2009).

\section{CONCLUSION}

The 37 blue glass beads analysed by LA-ICP-MS in this study have trace element compositions consistent with glass manufactured in Mesopotamia, therefore represent the only confirmed finished object of Mesopotamian glass to be discovered in Egypt. The major element composition is consistent with that of standard Late Bronze Age plant ash glass but potentially represents two main compositional groups; a low $\mathrm{MgO}$ group and a high $\mathrm{MgO}$ group, suggesting that these beads were manufactured from two different batches of glass. A pure form of copper was used as a blue colourant, as opposed to a bronze source which was typically the practice in LBA Egyptian glass technology. The beads were excavated from a previously undisturbed tomb, which contained the remains of seven women and two children. The tomb, and therefore the beads were dated from between the reign of Amenhotep I (1525-1504 BC) and Tuthmosis III (1479-1425 BC), and are therefore some of the earliest glass identified. The excavators implied that the women were foreign by the manner of the burial and from the associated grave goods and context (Brunton \& Engelbach, 1927, p10). The beads found in the tomb are certainly consistent with glass from the Near East. Evidence from the analysis of the beads should be considered 
alongside the isolated location of the "higher status" brick constructed tomb, which contained only females and children. The nearby harem palace may be the origin of these individuals, and it would be consistent with the evidence if the beads were brought to the among the personal effects transported into Egypt from Mesopotamia by women of status in connection with that palace

\section{ACKNOWLEDGMENTS}

The authors would like to thank the Hunterian Museum, Glasgow, for loaning the blue glass beads for this study. We also thank the reviewers who made suggestions, improving the clarity and strength of the paper.

\section{REFERENCES}

Aruz, J., Benzel, K. and Evans, J. M. (eds) (2008) Beyond Babylon: art, trade, and diplomacy in the second millennium B.C. New York: Yale University Press (Metropolitan Museum of Art).

Brunton, G. and Engelbach, R. (1927) British School of Archaeology in Egypt and Egyptian Research Account, Twenty Fourth Year, 1918 - Gurob. London: British School of Archaeology in Egypt.

Bryan, B. M. (2000) 'The Egyptian Perspective on Mittani', in Cohen, R. and Westbrook, R. (eds) Amarna Relations: The Beginnings of International Relations. Baltimore: Johns Hopkins University Press, pp. 71-84.

van Elteren, J. T., Tennent, N. H. and Šelih, V. S. (2009) 'Multi-element quantification of ancient/historic glasses by laser ablation inductively coupled plasma mass spectrometry using sum normalization calibration', Analytica Chimica Acta, 644(1-2), pp. 1-9.

Feucht, E. (1999) 'Jewelry', in Bard, K. (ed.) Encyclopedia of the Archaeology of Ancient Egypt. Oxford: Routledge, pp. 385-387.

Freestone, I. C. (1991) 'Looking into Glass', in Bowman, S. (ed.) Science and the Past. London: British Museum Press, pp. 37-56.

Henderson, J. (1998) 'Scientific analysis of glass and glaze from Tell Brak and its archaeological implications', in Oates, D., Oates, J., and McDonald, H. (eds) Excavations at Tell Brak, Volume 1: The Mitanni and Old Babylonian periods. Cambridge: McDonald Institute Monographs, pp. 94-98.

Hodgkinson, A. K. (2017) Technology and Urbanism in Late Bronze Age Egypt (Oxford Studies In Egyptian Archaeology). Oxford: OUP Oxford.

Ikram, S. (2015) Death and Burial in Ancient Egypt. American University in Cairo Press (American University in Cairo Press Series).

Jackson, C. M. and Nicholson, P. T. (2007) Brilliant things for Akhenaten: The Production of Glass, Vitreous Materials and Pottery at Amarna Site O45.1. Edited by P. T. Nicholson. London: Egypt Exploration Society.

Jackson, C. M. and Nicholson, P. T. (2010) 'The provenance of some ingots from the Uluburun shipwreck', Journal of Archaeological Science, 37(2), pp. 295-301.

Jochum, K. P. et al. (2011) 'Determination of reference values for NIST SRM 610-617 glasses following ISO guidelines', Geostandards and Geoanalytical Research, 35(4), pp. 397-429.

Kaczmarczyk, A. and Hedges, R. E. M. (1983) Ancient Egyptian faience: an analytical survey of Egyptian faience from predynastic to Roman times. Warminster: Aris and Phillips.

Kemp, B. J. (2006) Ancient Egypt: Anatomy of a civilization. 2nd edn. London: Routledge. 
Lilyquist, C. et al. (1993) 'Part 2. Glass', in Lilyquist, C. and Brill, R. H. (eds) Studies in Ancient Egyptian Glass. New York: Metropolitan Museum of Art, pp. 23-58.

Lilyquist, C. (2004) The Tomb of Three Foreign Wives of Tuthmosis III. New York: Yale University Press.

Liverani, M. (2000) 'The Great Powers' Club', in Cohen, R. and Westbrook, R. (eds) Amarna Relations: The Beginnings of International Relations. Baltimore, pp. 15-27.

Lucas, A. and Harris, J. R. (1962) Ancient Egyptian Materials and Industries. 3rd edn. London: Edward Arnold \& Co.

Moran, W. L. (1992) The Amarna Letters. Baltimore: The Johns Hopkins Press.

Nicholson, P. T. (1993) Ancient Egyptian Faience and Glass. London: Shire Egyptology.

Pusch, E. and Rehren, Th. (2007) Rubinglass für den Pharao: Hochtemperatur-Technologie in der RamsesStadt. Hildesheim: Gerstenburg.

Shaw, I. (2011) 'Seeking the Ramesside royal harem: new fieldwork at Medinet el-Gurob', in Collier, M. and Snape, S. (eds) Ramesside Studies in Honour of Ken Kitchen. Bolton: Rutherford Press, pp. 453-63.

Shortland, A. J. (2005) 'The raw materials of early glasses: the implications of new LA-ICPMS analyses', in Cool, H. (ed.) Proceedings of the 16th International Congress of the Association Internationale pour l'Histoire du Verre, London 2003. London.

Shortland, A. J. (2012) Lapis Lazuli from the Kiln : Glass and Glassmaking in the Late Bronze Age. Leuven: Leuven University Press.

Shortland, A. J. et al. (2017) 'The analysis of Late Bronze Age glass from Nuzi and the question of the origin of glassmaking', Archaeometry.

Shortland, A. J., Rogers, N. and Eremin, K. (2007) 'Trace element discriminants between Egyptian and Mesopotamian Late Bronze Age glasses', Journal of Archaeological Science, 34(5), pp. 781-789.

Shortland, A. J. and Tite, M. S. (2000) 'Raw materials of glass from Amarna and implications for the origins of Egyptian glass', Archaeometry, 42(1), pp. 141-153.

Smirniou, M. and Rehren, Th. (2011) 'Direct evidence of primary glass production in Late Bronze Age Amarna, Egypt', Archaeometry, 53(1), pp. 58-80.

Smirniou, M. and Rehren, Th. (2013) 'Shades of blue - cobalt-copper coloured blue glass from New Kingdom Egypt and the Mycenaean world: A matter of production or colourant source?', Journal of Archaeological Science, 40, pp. 4731-4743.

Snape, S. (2014) The Complete Cities of Ancient Egypt. London: Thames and Hudson Ltd.

Spalinger, A. (1977) 'A Critical Analysis of the “Annals” of Thutmose III (Stücke V-VI)', Journal of the American Research Center in Egypt. American Research Center in Egypt, 14, pp. 41-54.

Rehren, Th (2016) 'Another order for glass - or: how much glass does Pharaoh need?'

Tite, M. S. and Shortland, A. J. (2008) Production Technology of Faience and Related Early Viteous Materials. Oxford: Oxford University School of Archaeology (Monograph (Oxford University School of Archaeology)).

Varberg, J. et al. (2016) 'Mesopotamian glass from Late Bronze Age Egypt, Romania, Germany, and Denmark', Journal of Archaeological Science, 74, pp. 184-194.

Vicenzi, E P et al. (2002) 'Microbeam characterisation of Corning archaeological reference glasses: new additions to the Smithsonian Microbeam standard collection', Journal of Research of the National Institute Standards and Technology, 107, pp. 719-727.

Vicenzi, E. P. et al. (2002) 'Microbeam characterization of Corning archeological reference glasses: New additions to the Smithsonian microbeam standard collection', Journal of Research of the National Institute of Standards and Technology, 107(6), pp. 719-727.

Wagner, B. et al. (2012) 'Critical assessment of the elemental composition of Corning archeological reference glasses by LA-ICP-MS’, Analytical and Bioanalytical Chemistry, 402(4), pp. 1667-1677. 
Walton, M. et al. (2009) 'Evidence for the trade of Mesopotamian and Egyptian glass to Mycenean Greece', Journal of Archaeological Science, 36, pp. 1496-1503.

Walton, M. S. et al. (2009) 'Evidence for the trade of Mesopotamian and Egyptian glass to Mycenaean Greece', Journal of Archaeological Science, 36, pp. 1496-1503.

Wreszinski, W. (1923) Atlas zur altaegyptischen Kulturgeschichte. Leipzig: J.C. Hinrichs. 